\title{
AN UNUSUAL CASE OF MENINGIOMA WITH THE INVOLVEMENT OF RUSSELL'S HOOK BUNDLE AS DESCRIBED BY VITTORIO MARCHI (1851-1908)
}

THE name of Vittorio Marchi (1851-1908) is associated generally with the famous method of staining degenerating myelin which he discovered in 1885. Little is known about his person or his life. Having graduated as an M.D. and with a Ph.D. in Pharmacology from the University of Modena, Marchi spent four years as Assistant, first to Golgi and later to Luciani. Having failed to obtain the Chair of Histology at the University of Palermo and, equally, the Chair of Anatomy at Perugia, he retired at thirty-six to private practice at S. Benedetto del Tronto, Ascoli Piceno, and later became Physician-in-Chief at the Jesi Hospital where he spent the rest of his life.

$\mathrm{He}$ is often quoted as an example of serendipity: the 'country general practitioner' who made the ingenious discovery by working in the kitchen of his house. This does not do him justice. Marchi's scientific thoroughness ranked him among the most quoted investigators in histology of our time. His scientific memoir, On the Origin and Course of Cerebellar Peduncles (Florence, LeMonnier, 1885) which made him famous and won him a prize awarded from the R. Istituto Lombardo di Scienze e Lettere, still makes enjoyable and profitable reading, notwithstanding the eighty-five years that have elapsed since its publication.

Apart from his scientific achievements, like the neurohistologists Carl Weigert and Pio del Rio Hortega, he was always too honest and too scientifically minded for the frustrations and intrigues of an academic career. The 'business of science' is not often very profitable for scientists and is a good proposition only for those satisfied to be backroom boys doing minutely detailed routine research work.

The case described here was found among unpublished papers and notes of Dr. Marchi and deals with the illness and death of a young man, Enrico Cattani, who was thrown from his horse during army manoeuvres on 4 August 1895. He lost consciousness for several hours and was admitted to Ancona Hospital. Twelve days after recovery, he returned to active service, but 'his character was changed, he was more thoughtful and nearly indifferent to the environment. On 13 September 1896, that is to say 13 months after the fall, he was discharged and sent back home where he resumed his rural living'. Marchi reports here that relatives and friends noticed a change, not only in his character, but also in his gait-'he was carrying his head high, with stiff neck, strutting along and thoughtful in such a way that his friends and colleagues thought he was doing it in jest'. After a five-month period the patient began to be troubled with a diffuse weakness and headaches. These symptoms became worse and weakness was evident, above all in the inferior limbs: 'feeling worse and worse because of the headaches and the weakness of the legs, he came to be examined by ourselves'.

During the first examination, Marchi-who was at that time Physician-in-Chief of the Hospital in Jesi-did not diagnose the illness because the symptoms were not sufficiently clear. But as the affliction progressed he noticed 'a disorder in motility resulting from inco-ordination of the legs, stiffness of the neck, a slight tendency to fall backwards and to the right and a right side hyperreflexia; when someone gave 


\section{News, Notes and Queries}

him an object he took it slowly and with uncertain movements; every time he ate there was some vomiting; his senses of smell and hearing were normal; he exhibited a noticeable loss of weight; there was no loss of consciousness and no vertigo. The latter only arose during the last days of his life, so that he was obliged to keep to his bed and forced to lie on his left side'. The diagnosis was-'cerebellar tumor localized mostly on the right'. The autopsy findings showed that-'all the right and posterior part of the cerebellum consisted of a tumor of oval shape, round-topped and which indented deeply into cerebellar matter; in the middle of it there was a cyst of the size of a small egg filled with a serous liquid'. On closer examination the tumour was found to be localized on the inferior side of the right hemisphere with involvement of the vermis. Histological examination showed that the tumour was an endotelioma, i.e. a meningioma arising probably from mesothelial cells of arachnoidal villi.

Marchi first established the connexion between the trauma and the tumour-'it is to be supposed that the fall produced a small haemorrhage and a cyst, which, in turn, primed some months later the growing of the tumour'. This correlation was found to be true and, some forty years later, was confirmed again by the authoritative survey by Cushing and Eisenhardt. ${ }^{1}$ It is to be added that a meningioma in that region of the brain is quite unusual because the usual sites of these tumours are in the olfactory groove, the tuberculum sellae, the lesser wing of the sphenoid bone and, more frequently, the convex surface of the brain and the region of the sagittal sinus. The clinical picture was that of a caudal vermis syndrome which Marchi diagnosed with great accuracy, if we remember that in his time studies on cerebellar localization were in their early stages.

In fact an experimental lesion destroying the posterior part of the vermis including the nodule causes the head of the monkey to tilt backward, ${ }^{2}$ whereas larger lesions, which completely destroy the posterior vermis (both the vermal cortex and the underlying fastigial nuclei) render the animal hypotonic with a crouched wide-based gait. Obviously hypotonia and ataxia-which are the major cerebellar symptoms-are also attributable to the concomitant lesion of the hemisphere. It is to be noted here that Marchi did not mention nystagmus, which should have been present with such a deep but asymmetrical lesion. Histological examination of serial sections of the spinal cord by means of the author's own method for degenerating myelin showed: 'degeneration in the antero lateral column of the spinal cord. This degeneration is found when the cerebellum is destroyed and it is not dependent on lesion of Deiters' nuclei, which in the present case were normal, as some Authors claim, but is especially dependent on the lesion of the superior part of the cerebellum, as the Author himself has shown in one of his papers and it is found not only in animals but also in man'.

In fact, as already mentioned in On the Origin and Course of Cerebellar Peduncles, Marchi stated that extirpation of the cerebellum (or of its parts) gave rise to a degeneration of a bundle of fibres running in the antero-lateral column of the spinal cord and ending on the cervical motoneurons. These cells, in fact, showed clear signs of chromatolysis. There is no doubt that, from the above description and from the clinical signs, Marchi was dealing with the degeneration of fibres of Russell's hook bundle. If he did not recognize their anatomical identity it is because the first description of this bundle was given by the English neurologist, Risien Russell, in 


\section{News, Notes and Queries}

the same year, $1895 .^{3}$ This bundle, which originates in the nucleus fastigii, arches forward to join fascicles of superior cerebellar peduncle, then turns backward and downward to leave the cerebellum by the juxtarestiform part of the inferior cerebellar peduncle. It proceeds caudalwards and enters the spinal cord-where it ends on cervical motoneurons-as part of the vestibular component of the sulcomarginal fasciculus. Quite recently, ${ }^{4,5}$ its function has been correlated with changes in the position of the head, which in the present case was severely involved.

It is interesting to remark that, though Marchi did not mention specifically this fasciculus, its course and its physiological meaning were exactly understood in his notes, and any connexion with vestibular (Deiters') nuclei was denied. Moreover, it should be remembered that Russell's description of this fascicle was from an experimental animal and this is certainly the first case in which it showed its degeneration in man.

\section{SUMMARY}

In unpublished notes-probably drafted for a clinicopathological conference-the Italian neurologist and neuroanatomist Vittorio Marchi of Novellara (1851-1908) gives an account of a cerebellar meningioma following a fall from a horse thirteen months earlier. The tumour involved the vermis and the right part of cerebellar hemisphere giving rise to a picture of the caudal vermis syndrome. Histological sections, stained by Marchi's own method, showed an area of degeneration in the anterolateral column of the cervical spinal cord. The fibres can be recognized as those of Russell's hook bundle concerned with the regulation of head movements described in experimental animals in the same year, 1895.

\section{ACKNOWLEDGEMENTS}

I wish to thank the late Prof. V. Duse of Padova for having so kindly given me the opportunity of studying the manuscripts of his maternal grandfather, and Miss Marianne Winder for her assistance in the preparation of this paper.

\section{REFERENCES}

1. Cushing, H. W. and EIsenhardt, L., Meningiomas. Their Classification, Regional Behaviour, Life History and Surgical End Results, Springfield, Illinois, Thomas, 1938.

2. Crosby, E. C., Schneider, R. C., De Jonge, B. R. and Szony, P., J. comp. Neurol., 1966, 127, suppl. 1, 22.

3. Risien Russell, J. S., Phil. Trans. R. Soc. Lond., Series B, 1895, 186, 633.

4. JANSEN, J. and JANSEN, J. jr., J. comp. Neurol., 1955, 102, 607.

5. Carpenter, M. B., Am. J. Anat., 1959, $104,1$.

A complete list of the publications of Dr. Marchi, from his original curriculum vitae, is reproduced in full in L. Lucian,, Arch. it. Biol., 1908, 39, 149-52.

ANTONIO A. RIZZOLI 